\title{
Gastric emptying of liquid in children suffering from acute rotaviral gastroenteritis
}

\author{
P K Bardhan, M A Salam, A M Molla
}

\begin{abstract}
Nausea and vomiting commonly occur in children suffering from rotaviral diarrhoea. Gastric emptying was studied in $\mathbf{1 0}$ children (age six to 12 months) suffering from acute diarrhoea caused by rotavirus using a dye dilution double sampling technique. The test meal was $5 \%$ dextrose in water and this test was repeated 12 weeks after recovery. The median (range) of the percentages of the liquid meal remaining in the stomach at $5,10,20,40$, and 60 minutes after instillation of the meal were 82 (79-90), 70 (61-86), 51 (38-76), 26 (14-53), and 13 (2-35) respectively in the acute stage, whereas after the recovery period the values were 76 (70-79), 58 (49-63), 33 (24-40), 11 $(2-26)$, and $3(0-7)$. The differences were statistically significant. The half time of gastric emptying ( $\left.t^{1 / 2}\right)$ was $19.5(14-30)$ minutes in acute stage, and 13.1 (10-15) minutes during follow up $(p<0.01)$. Rotaviral gastroenteritis is accompanied by abnormal gastric motor function, as manifested by delayed emptying of a liquid meal.
\end{abstract}

Among the different microbial pathogens causing acute diarrhoea in children below the age of two years, rotavirus is the most common pathogen. ' Rotaviral gastroenteritis is characterised by nausea, vomiting, dehydrating diarrhoea, and associated constitutional symptoms of varying degrees, generally followed by complete recovery without sequelae. ${ }^{2}$ Characteristic histological lesions have been noted in the proximal small intestinal mucosa after infection with rotavirus, ${ }^{3}$ although no consistent morphological change in the gastric mucosa can be identified. ${ }^{4}$

Abnormal gastric emptying has been described in several medical conditions associated with anorexia, nausea and vomiting, including gastrooesophageal reflux, gastric ulcer, anorexia nervosa and in diabetic enteropathy. ${ }^{5}$ In patients suffering from rotaviral gastroenteritis, the prominence of nausea and vomiting as presenting symptoms suggests abnormal gastric function during the actual illness, despite the absence of apparent infection of the gastric mucosa. A marked delay of gastric emptying has been observed in healthy adult volunteers developing diarrhoea after ingestion of Norwalk and Hawaii agents. ${ }^{6}$ No reports about gastric emptying in children suffering from acute rotaviral enteritis are available. The frequent occurrence of anorexia, nausea, and vomiting early in the course of rotaviral infections often causes concerns about the tolerance of oral rehydration solutions in these patients. The present study was designed to ascertain whether there is any impairment in gastric emptying of liquids in children below two years of age suffering from acute rotaviral gastroenteritis.

\section{Methods}

Ten children below two years of age suffering from acute watery diarrhoea of less than 48 hours duration were included in the study. All experienced nausea and vomiting from the onset of the illness, none had clinical evidence of a systemic illness, and none had received any antidiarrhoeal agents or antibiotics before admission. Informed written consent was obtained from the parents before inclusion in the study.

Initial rehydration and subsequent maintenance of hydration was carried out with intravenous fluids only until the gastric emptying test was completed, after which the standard glucose-electrolyte oral rehydration solution was provided if required. Blood samples were analysed for blood count, haemotocrit, electrolytes, creatinine, and protein content. Stool samples were sent for microscopic examination and comprehensive bacteriological culture, and examination for rotavirus by enzyme linked immunosorbent assay (ELISA) technique. The data from those patients from whom only rotavirus and no other pathogens were isolated are presented here. Gastric emptying measurements were made in the acute stage of the disease and in each case, 12 weeks later when the patient was asymptomatic.

\section{ASSESSMENT OF GASTRIC EMPTYING}

The double sampling marker dilution technique of George ${ }^{7}$ was used to measure gastric emptying. This technique requires the determination of marker concentration in gastric samples before and after instillation of a concentrated marker. The gastric volume is calculated from the change in the concentration of the marker, polyethelyene glycol (PEG 4000). ${ }^{8}$ Initial concentration of polyethelyene glycol in the test meal was $5 \mathrm{~g} / \mathrm{l}$ of $5 \%$ dextrose in water, and the concentration of polyethelyene glycol used for preparing the concentrated marker solution was $50 \mathrm{~g} / \mathrm{l}$ of $5 \%$ dextrose in water. Both the test meal and the concentrated marker solution were freshly prepared each day.

After a six hour fast, a paediatric sized nasogastric tube was passed into the stomach, without any sedation, and then positioned into the most dependent part of the stomach. ${ }^{\circ}$ After 15 to 20 minutes resting gastric juice was aspirated, and the stomach washed out with distilled water. Then the test meal $(20 \mathrm{ml} / \mathrm{kg}$ body wt) was instilled through the nasogastric tube into the stomach within the period of two minutes. At five minutes, a $2.5 \mathrm{ml}$ sample of gastric juice was 
aspirated and stored, and $5 \mathrm{ml}$ of the concentrated marker solution was injected into the stomach. Gastric contents were thoroughly mixed over a one minute period by repeated rapid aspiration and reinjection of $15 \mathrm{ml}$ volumes of gastric contents using a $20 \mathrm{ml}$ syringe. After mixing, another $2.5 \mathrm{ml}$ sample was aspirated and stored. This procedure was repeated at 10 minutes, 20 minutes, and then every 20 minutes until the volume of aspirate became less than $2 \cdot 5$ $\mathrm{ml}$. The polyethelyene glycol concentration of the stored gastric aspirates was measured by a turbidimetric method. ${ }^{10}$

The volume of the test meal remaining at each step was calculated according to the method of Beckers et $a l^{11}$ which allows volume calculation in the stomach rather than total volume of gastric contents which included gastric secretion, swallowed saliva and the test meal. The calculation procedure of George ${ }^{7}$ modified by Siegel $e t$ $a l^{12}$ is as follows:

$$
V_{n b}^{s}=V_{n}^{i} \cdot \frac{C_{n}^{i}-C_{n a}^{s}}{C_{n a}^{s}-C_{n b}^{s}}+1 / 2 V_{n}^{i}
$$

where $\mathrm{V}_{\mathrm{bn}}^{\mathrm{s}}=$ volume of gastric contents before adding marker solution; $\mathrm{V}^{\mathrm{s}}{ }_{\mathrm{na}}=$ volume of gastric contents after adding marker solution; $\mathrm{V}_{\mathrm{n}}^{\mathrm{i}}=$ volume of concentrated marker solution added; $\mathrm{C}_{\mathrm{nb}}^{\mathrm{s}}=$ concentration of polyethelyene glycol before adding concentrated marker solution; $\mathrm{C}_{\mathrm{na}}^{\mathrm{s}}=$ concentration of polyethelyene glycol after adding concentrated marker solution; $\mathrm{C}_{\mathrm{n}}=$ concentration of polyethelyene glycol in the concentrated marker solution.

Thereafter, the volume of test meal remaining at determination number $\mathrm{n}$ was calculated according to the following general formula: ${ }^{11}$

$$
V_{n}^{t}=\frac{A_{n b}}{A_{(n-1) a}} \cdot \frac{A_{(n-1) b}}{A_{(n-2) a}} \ldots \frac{A_{2 b}}{A_{1 a}} \cdot V_{1}^{t}
$$

where $\mathrm{V}_{\mathrm{n}}^{\mathrm{t}}=$ volume of test meal; $\mathrm{A}_{\mathrm{nb}}=$ amount of polyethelyene glycol in gastric contents before adding concentrated marker solution; $A_{n a}=$ amount of polyethelyene glycol in gastric contents after adding concentrated marker solution

TABLE I Clinical characteristics of the study population on admission

\begin{tabular}{lc}
\hline Age (mo) & $9(6-14)$ \\
Wt age \% of NCHS median & $81(76-83)$ \\
$\begin{array}{l}\text { Duration of diarrhoea before } \\
\text { hospitalisation (h) }\end{array}$ & $36(20-48)$ \\
Haematocrit & $33(30-37)$ \\
Specific gravity (serum) & $1 \cdot 024(1 \cdot 021-1 \cdot 026)$ \\
Serum $\mathrm{Na}^{+}$ & $139(136-142)$ \\
Serum $\mathrm{K}^{+}$ & $3.9(3 \cdot 7-4 \cdot 1)$ \\
Serum $\mathrm{Cl}^{-}$ & $92(87-98)$ \\
Serum $\mathrm{TCO}_{2}$ & $21 \cdot 8(18 \cdot 6-23 \cdot 0)$ \\
\hline
\end{tabular}

Results are expressed as median (range)

TABLE II Percentage of test meal remaining in the stomach at different time intervals

\begin{tabular}{lll}
\hline (Min) & During acute illness & After full recovery \\
\hline $5^{\star}$ & $82(79-90)$ & $76(70-79)$ \\
$10^{\star}$ & $70(61-86)$ & $58(49-63)$ \\
$20^{\star}$ & $51(38-76)$ & $34(24-40)$ \\
$40^{\star}$ & $26(14-53)$ & $11(2-16)$ \\
$60^{\star}$ & $13(2-35)$ & $3(0-7)$ \\
$\mathrm{T}_{1 / 2}(\min )^{\star}$ & $19 \cdot 5(14-30)$ & $13 \cdot 1(10-15)$ \\
\hline
\end{tabular}

${ }^{\star} \mathrm{p}<0.01$. Results are expressed as median (range).
The abbreviations used are: $\mathrm{V}=$ volume $(\mathrm{ml})$; $\mathrm{C}=$ concentration of polyethelyene glycol $(\mathrm{mg} /$ $\mathrm{ml}$ ). Raised suffixes are: $\mathrm{A}=$ amount of marker in gastric content; $\mathrm{s}=$ gastric contents; $\mathrm{i}=$ marker; $\mathrm{t}=$ test meal. Lower suffixes are: $\mathrm{n}=$ the serial number of observation; $b=$ before adding the concentrated mark; $a=$ after adding the concentrated marker.

\section{STATISTICAL ANALYSIS}

Fraction of the original volume of test meal remaining in the stomach at the different time intervals were calculated separately for each patient, and mean curves were constructed from the data points. For every time point, gastric emptying patterns in patients during the acute illness and after full recovery from the illness were compared by using Wilcoxon's signed-rank test; also data were submitted to power exponential analysis. ${ }^{13}$ The parameters $t_{1 / 2}$ and $\beta$ were estimated from the fitted power exponential curve. According to this model,

$$
\mathrm{f}=2^{-\left(\mathrm{t} / \mathrm{t}_{1 / 2}\right)^{\beta}}
$$

where $f$ is the proportion of the test meal remaining at time $t$, and $t_{1 / 2}$ is the time at which half the original meal has emptied, that is the half time of emptying. The parameter $\beta$, in the power exponential, determines the shape of the curve.

The half times for emptying $\left(t_{1 / 2}\right)$ were calculated from the plotted curves, and the $t_{1 / 2}$ in each patient during illness and after recovery were compared by Wilcoxon's paired signed-rank test.

\section{Results}

The clinical status of the 10 patients is summarised in Table I. None of the children was malnourished, dehydrated, or had electrolyte imbalance at the time of admission to the study. The volumes of test meal remaining in the stomach after $5,10,20,40$, and 60 minutes are summarised in Table II. Significant difference between volumes of the test meal remaining in the stomach during the acute illness and that after full recovery were noted in all the time intervals. Half times of gastric emptying $\left(t_{1 / 2}\right)$ calculated from the emptying curves of each gastric emptying test are shown in Table II. A significant delay occurred during the acute stage of illness when compared with the state after recovery $(p<0.01)$. The values of $\beta$ were 1.08 $(0.07)$ in the acute state, and $1.04(0.04)$ after recovery, suggesting that gastric emptying occurred in a nearly simple linear exponential model (Figure). The values of the correlation coefficient $\mathrm{r}^{2}$ shows that the curve fitting procedure was satisfactory. The absence of any significant difference in $\beta$ during the acute illness and that after full recovery suggested that despite the delayed gastric emptying during the acute illness, the pattern of gastric emptying is not different.

\section{Discussion}

A marked delay of gastric emptying of liquids occurred in children suffering from acute rota- 


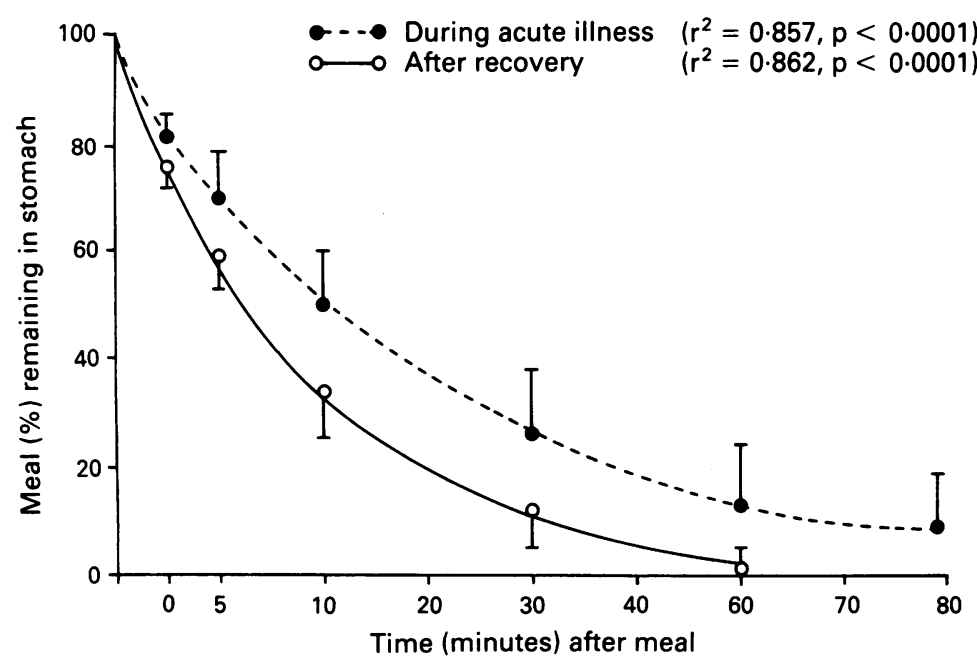

Gastric emptying patterns described by mean residual gastric volumes. Results are mean (SD).

viral enteritis. Delayed emptying of a test meal from the stomach during the acute illness was noted when compared with that of after recovery in all the time intervals during acute illness compared with values obtained after recovery. These findings are consistent with earlier observations of delayed gastric emptying in adult volunteers after ingestion of Norwalk and Hawaii viruses, ${ }^{6}$ but the delay noted in our group of patients was less marked than that of the earlier study. Gastric emptying of liquids is believed to be primarily a function of the pressure gradient between the stomach and the duodenum. ${ }^{14}$ Factors known to influence gastric emptying of liquids are volume of the liquid in the stomach and the composition of the liquid which includes osmolarity, $\mathrm{pH}$, nutritive density and fat or amino acid content. ${ }^{\text {is }}$ These factors exert their influence on the contractile activity of the stomach by poorly characterised neural and hormonal pathways through specific small bowel receptors. These receptors are located in the duodenum and the upper jejunum ${ }^{16}$ and their exact nature is still undefined, although it has been proposed that the lateral intercellular spaces between the duodenal enterocytes can act as the single transducer of these stimuli. ${ }^{17}$ Thus any injury to the upper small bowel mucosa is likely to have adverse effects on normal gastric emptying. Experimental injury to the small intestinal mucosa induced by various chemical agents has been seen to delay gastric emptying to a degree closely correlated with the severity of mucosal injury. ${ }^{18}$ Staphylococcal enterotoxin B, which causes mild, short lived villus injuries in rhesus monkeys ${ }^{19}$ also is capable of inducing gastric retention. ${ }^{20}$ Histological examination of small intestinal mucosa of infants and young children with rotaviral gastroenteritis as well as in experimental animal models revealed varying degrees of structural lesion characterised by destruction of the enterocytes lining the small intestinal villi and progressive shortening of the villi, increases in crypt depth, and reduction of mucosal brush border enzymes. ${ }^{2122}$ Considering these facts, the delay in gastric emptying noted in the present study is not surprising or unexpected.

That the cause of the delayed gastric emptying is related to the rotavirus infection and not to any disturbance of the body fluids is evident from the normal serum electrolyte levels. Also, the patients were well hydrated at the time of carrying out the studies, as judged by their haematocrit and serum specific gravity values.

The mechanism of this delay in gastric emptying can not be explained from the present study. Gastrointestinal hormones, such as secretin, gastrin and glucagon can delay gastric emptying ${ }^{23}$ but only cholecystokinin is believed to exert its influence at physiological doses. ${ }^{24}$ The status of these hormones in rotaviral enteritis is still unknown. Neural pathways influencing gastric emptying mediated by non-cholinergic, nonadrenergic, and partially dopaminergic vagal neurones ${ }^{5}$ may also be involved, and alterations in central nervous system controls of gastric emptying cannot be ruled out.

Gastric emptying and food intake are intimately related, ${ }^{25}$ and a significant reduction in food intake has been observed in children suffering from acute rotaviral enteritis. ${ }^{26}$ Whether pharmacological modulation of gastric emptying - for example, by cholecystokinin blockers could lead to a reduction in intensity of nausea and vomiting and increased food intake in these children remains to be investigated. Also, despite the prominence of nausea and vomiting in acute rotavirus infection, the fact that the gastric emptying delay is not more severe may explain why oral rehydration therapy remains a rational approach to the management of dehydration in this condition.

We would like to thank J R Hamilton and Klaus Gyr for manuscript review, and M A Majid Khan for secretarial assistance. This research was supported by the International Centre for Diarrboeal Disease Research, Bangladesh (ICDDR,B). The ICDDR,B is supported by countries and agencies which share its ICDDR,B is supported by countries and agencies which share its
concern about the impact of diarrhoeal diseases on the developing concern about the impact of diarrhoeal diseases on the developing
world. Current major donors giving assistance to ICDDR, B are: world. Current major donors giving assistance to ICDDR,B are: The Aga Khan Foundation, Arab Gulf Fund, Australia, Bangla-
desh, Belgium, Canadian International Development Agency desh, Belgium, Canadian International Development Agency (IDRC), Danish International Development Agency (DANIDA), France, The Ford Foundation, Japan, The Netherlands, Norwegian Agency for International Development (NORAD), SAREC (Sweden), Swiss Development Co-operation (SDC), United Kingdom, United Nations Development Programme (UNDP), United Nations Children's Fund (UNICEF), United Nations Capital Development Fund (UNCDF), United States Agency for International Development (USAID), World Health Organization (WHO), and World University Service of Canada (WUSC).

1 Black RE, Merson MH, Rahman AS, Yunus M, Alim AR, Huq I,et al. A two year study of bacterial, viral parasitic
agents associated with diarrhoea in rural Bangladesh. agents associated with diarr

2 Flewet TH. Clinical features of rotavirus infections. In: Tyrell DAJ, Kapikian AZ, eds. Virus infections of the gastrointestinal tract. New York: Marcel Dekker, 1982: 125-46.

3 Davidson GP, Gall DG, Petric M, Butler DH, Hamilton DG. Human rotavirus gastroenteritis induced in conventional piglets. Intestinal structure and transport. $\mathcal{F}$ Clin Invest 1977; 60: 1402-9.

4 Widerlite L, Trier JS, Blacklow NR, Schriefer DS. Structure of gastric mucosa in acute infectious non-bacterial gastroenteritis. F Infect Dis 1974; 129: 705-8.

5 Minami H, McCallum RW. The physiology and pathophysiology of gastric emptying in humans. Gastroenterology 1984; 86: 1592-610.

6 Meeroff JC, Schrieber DS, Trier JS, Blacklow NR. Abnormal gastric motor function in viral gastroenteritis. Ann Intern
Med 1980; 92: 370-3.

7 George JD. New clinical method for measuring the rate of gastric emptying: the double sampling test meal. Gut 1968; 9: $237-42$.

8 Ivey KJ, Schedl HP. Gastric non-absorbable indicators for studies in man. Gastroenterology 1970; 59: 234-9.

9 Hassan MA, Hobsley M. Position of subject and of nasogastric tube during a gastric secretion study. BMF 1970; 1: 458-60.

10 Hyden S. A turbidimetric method for determination of higher polyethylene glycols in biological materials. Kungl Lantbrukshogsk Ann 1956; 22: 139-45.

11 Beckers EJ, Rehrer NJ, Brouns F, Ten Hoor F, Saris WHM. 
Determination of total gastric volume, gastric secretion and residual meal using the double sampling technique of George. Gut 1988; 29: 1725-9.

12 Siegel M, Lebenthal E, Topper W, Krantz B, Li PK. Gastric emptying in prematures of isocaloric feedings with differing osmolalities. Pediatr Res 1982; 16: 141-7.

13 Elashoff JD, Ready TJ, Meyer JH. Analysis of gastric emptying data. Gastroenterology 1982; 83: 1306-12.

14 Strunz UT, Grossman MJ. Effect of intragastric pressure on gastric emptying and secretion. Am $\mathcal{F}$ Physiol 1978; 234: 552-5.

15 Hunt JN. Mechanisms and disorders of gastric emptying. Annu Rev Med 1983; 34: 219-29.

16 Cooke AR. Localisation of receptors inhibiting gastric emptying in the gut. Gastroenterology 1977; 72: 875-80.

17 Barker GR, Cochrane GM, Corbett GA, Dulton JF, Hunt JN, Roberts SK. Glucose, glycine and diglycine in test meals as stimuli to a duodenal osmoreceptor slowing gastric emptying. F Physiol (Lond) 1978; 283: 341-6.

18 Kent TH, Cannon B, Reynolds JA, Osborne JW. Gastric emptying and small intestinal mucosal injury in rats. Gastroenterology 1975; 69: 1246-53.
19 Kent TH. Staphylococcal enterotoxin gastroenteritis in rhesus monkeys. Am ₹ Pathol 1965; 48: 387-407.

20 Elwell MR, Liu CT, Spertzel RO, Biesel WR. Mechanisms of oral staphylococcal enterotoxin B induced emesis in monkeys. Proc Soc Exp Biol Med 1975; 148: 424-7.

21 Davidson GP, Barnes GL. Structural and functional abnormalitis of the small intestine in infants and young childre with rotavirus enteritis. Acta Paediatr Scan 1976; 68: 181-6.

22 Graham Dy, Sackman JW, Estes MK. Pathogenesis of rotavirus induced diarrhoea: preliminary studies in miniature swine piglet. Dig Dis Sci 1984; 29: 1028-35.

23 Cooke AR. Control of gastric emptying and motility. Gastroenterology 1975; 68: 804-16.

24 Debas HT, Farooq O, Grossman MI. Inhibition of gastric emptying as a physiological action of cholecystokinin Gastroenterology $1975 ; 68: 1211-7$.

25 Hunt JN. A possible relation between the regulation of gastric emptying and food intake. $A m$ J

26 Molla AM, Molla A, Sarker SA, Rahaman MM. Food intake during and after recovery from diarrhoea in children. In: Chen LC, Scrinushaw NS, eds. Diarrhoea and malnutrition. New York: Plenum Publishing, 1983: 113-23. 